DOI https://doi.org/10.30525/978-9934-26-038-4-24

\title{
PREDICTION OF POSTOPERATIVE COMPLICATIONS IN PATIENTS WITH PERITONITIS
}

\author{
Liesnyi V. V. \\ Ph.D. in Medicine, \\ Assistant at the Department of Surgery № 2 \\ Kharkiv National Medical University \\ Kharkiv, Ukraine \\ Liesna A. S. \\ Intern, \\ Assistant at the Department of Infectious Diseases \\ Kharkiv National Medical University \\ Kharkiv, Ukraine
}

Filonenko V. O.

Endoscopist at the Department of Emergency Operative Endoscopy

Regional Hospital of Intensive Care city Mariupol

Mariupol, Donetsk region, Ukraine

The complexity of the complex treatment of abdominal sepsis and postoperative complications maintain the mortality rate in diffuse peritonitis at the level of $30-66 \%$ [1, p. 491]. Despite the prominence of the main areas of treatment peritonitis: early hemodynamic support, source control and antimicrobial therapy [2, p. 3]. At the moment, many prognostic scales for intraabdominal infection are used, which have both advantages and disadvantages [3, p. 269].

The aim of our study was to analyse the prognostic significance of the scale of physiological and operational assessment of the risk of complications and mortality (POSSUM) in the treatment of patients with diffuse peritonitis.

Materials and methods. The work is based on the analysis of the results of treatment of 63 patients hospitalized in urgent manner for the period from 2015 to 2017 with acute abdominal pathology complicated by peritonitis. There were 49 men $(79 \%)$ and 14 women $(21 \%)$. The average age of men was $(58.5 \pm 1.5)$ years, women $-(65.2 \pm 1.6)$ years.

The severity of patients was verified according to the WSES Sepsis Severity Score criteria. Revealed signs: phenomena of immunosuppression $2(3.2 \%)$ patients, the duration of peritonitis (taking into account preoperative preparation) up to 24 hours $-60(95.2 \%)$, the source of peritonitis is the 
colon $-6(9.5 \%)$, the source of peritonitis the large intestine (diverticulum) $9(14.3 \%)$, the source of peritonitis is the small intestine $-11(17.5 \%)$.

All patients were operated on urgently in accordance with the protocols for the provision of urgent and emergency surgical care. Surgical intervention consisted in the elimination of abdominal pathology (appendectomy, cholecystectomy, resection of the small intestine), nasointesninal intubation, debridement, and drainage of the abdominal cavity.

According to the indicator, the sepsis severity score, patients were divided into three clinical groups: with I degree of severity ( $<7$ points) 31 (49.2\%) patients, II degree of severity (7-11 points) - 22 (34.9\%), III degree of severity (> 11 points) $-10(15.9 \%)$.

During hospitalization, the physiological parameters of the POSSUM scale were revealed: age under 60 years - $59(93.6 \%)$ patients; the level of consciousness (clear consciousness) - 61 (96.8\%); heart rate in the range of 81-100 per minute - 61 (96.8\%); shortness of breath on exertion or chronic obstructive pulmonary disease confirmed by plain chest x-ray $-27(42.8 \%)$; cardiac status (taking antihypertensive drugs) - $52(82.5 \%)$; systolic blood pressure less than $130 \mathrm{~mm} \mathrm{Hg}$. - 40 (63.5\%); haemoglobin <114 g/l $29(46 \%)$; leukocytosis $>(10-20) * 10^{9} / 1-60(95.3 \%)$; urea in the range of 7.6-10 mmol/l - $32(50.8 \%)$; plasma potassium 3.2-3.4 meq/l - 60 (95.3\%); plasma sodium 126-130 meq/l - $62(98.4 \%)$.

Research results. Patients with I degree of severity needed one surgical intervention to eliminate peritonitis. Postoperative complications were detected in $8(12.8 \%)$ patients. The index of physiological assessment on the POSSUM scale was $19 \pm 1.5$ points, the intraoperative criterion was $10 \pm 0.9$ points. The expected complication rate according to the POSSUM scale was assumed to be $11.7 \%(\mathrm{p}=0.3181)$.

Patients with the II degree of severity, the treatment of peritonitis was carried out by the method of laparotomy according to the program or on demand. The index of the physiological assessment on the POSSUM scale increased on average to $24 \pm 1.9$ points, and the increase in the operational assessment to $15 \pm 0.99$ points was due to a change in the nature of the effusion, expansion of the volume of surgery. At the same time, the predicted frequency of postoperative complications was $26.7 \%$, the actual $27.2 \%(\mathrm{p}=0.3231)$.

Vacuum-assisted laparostomy was used in patients with grade III severity. The physiological indicator was $34 \pm 2.6$ points, which is due to proteinelectrolyte disturbances against the background of dehydration, endogenous intoxication. The expected complication rate according to the POSSUM scale reached $68.4 \%$, while the actual rate was $70 \%(\mathrm{p}=0.3862)$.

The indicators of the POSSUM scale are reliably comparable with the actual incidence of postoperative complications in patients with diffuse peritonitis, which confirms the high sensitivity of the prognostic scale, and makes it possible to use it to select an individual surgical aid. 


\title{
References:
}

1. Bader FG, Schröder M, Kujath P, et al. Diffuse postoperative peritonitis - value of diagnostic parameters and impact of early indication for relaparotomy. Eur J Med Res. 2009 Nov 3;14(11):491-6. doi: 10.1186/2047-783x14-11-491.

2. Sartelli M, Viale P, Catena F, et al. 2013 WSES guidelines for management of intra-abdominal infections 2013 WSES guidelines for management of intra-abdominal infections. World J Emerg Surg. 2013;8(1):3. doi:10.1186/1749-7922-8-3

3. Eckmann C, Bassetti M. Prognostic factors for mortality in (fecal) peritonitis: back to the roots. Intensive Care Med. 2014;40(2):269-271. doi:10.1007/s00134-013-3155-x

DOI https://doi.org/10.30525/978-9934-26-038-4-25

\section{ПРОГНОЗ ЗВИЧНОГО НЕВИНОШУВАННЯ ВАГІТНОСТІ}

\author{
Лоскутова Т. О. \\ доктор медичних наук, \\ професор кафедри акушерства та гінекологіі \\ Д3 «Дніпропетровська медична академія \\ Міністерства охорони здоров'я Украӥни» \\ м. Дніпро, Украӥна
}

Давиденко Н. В.

лікар акушер-гінеколог

Комунальне некомериійне підприємство «Міська поліклініка № 4»

Дніпропетровської міської ради

м. Дніпро, Украӥна

Чулков О. С.

лікар-інтерн кафедри акушерства, гінекології та перинатології

факультету післядипломної освіти

Д3 «Дніпропетровська медична академія

Міністерства охорони здоров'я України»

м. Дніпро, Украӥна

Актуальність. Частота невиношування вагітності стабільно залишається високою та досягає 30 \% від кількості бажаних вагітностей. Статистично кожен другий випадок мимовільного переривання вагітності трапляється у 1 триместрі, а $25 \% 3$ них припадає на звичне 